\title{
Spatial distribution, biomass and population dynamics of Mysis relicta in Lake Michigan
}

\author{
Steven A. Pothoven ${ }^{1}$, Gary L. Fahnenstiel ${ }^{2}$ \& Henry A. Vanderploeg ${ }^{3}$ \\ ${ }^{1}$ Cooperative Institute of Limnology and Ecosystem Research, Great Lakes Environmental Research Lab/ \\ University of Michigan, Lake Michigan Field Station, 1431 Beach St, Muskegon, MI 49441, U.S.A. \\ E-mail: steve.pothoven@noaa.gov \\ ${ }^{2}$ Lake Michigan Field Station, National Oceanic and Atmospheric Administration, \\ Great Lakes Environmental Research Lab., 1431 Beach St, Muskegon MI 49441, U.S.A. \\ ${ }^{3}$ National Oceanic and Atmospheric Administration, Great Lakes Environmental Research Lab., \\ 2205 Commonwealth Blvd, Ann Arbor, MI 48105, U.S.A.
}

Received 20 November 2001; in revised form 5 December 2003; accepted 10 December 2003

Key words: Mysis relicta, Lake Michigan, Great lakes, zooplankton, spatial variation

\begin{abstract}
The abundance, biomass, and life history traits of Mysis relicta were evaluated in the spring, summer, and autumn of 2000 at 8 nearshore $(45 \mathrm{~m})$ and 8 offshore $(75-110 \mathrm{~m})$ stations throughout central and southern Lake Michigan. Abundance was also evaluated on a smaller scale during June 2000 at 4 nearshore and 4 offshore stations in southeastern Lake Michigan. For large-scale sampling, the abundance of $M$. relicta did not differ among locations in the spring. In the summer and autumn the abundance of M. relicta was similar among offshore stations with the exception of one station each season; for nearshore stations, abundance was generally highest off Pentwater, Michigan. The abundance of mysids was not consistently high for central or southern basin sites, although overall biomass was higher in the southern basin each season. Abundance of Mysis was positively correlated with bottom depth, but not with bottom water temperature, surface water temperature, or mean chlorophyll concentration. Within the smaller region in southeast Lake Michigan, the abundance of M. relicta differed among locations for both nearshore and offshore stations. Brood size and size of reproductive females did not differ among lake wide locations, but the proportion of females with broods and the size distribution of M. relicta did.
\end{abstract}

\section{Introduction}

The opossum shrimp, Mysis relicta Loven, is a freshwater macroinvertebrate found in glaciated areas of North America and Europe (Balcer et al., 1984). Mysis were also widely introduced as a food source for fish into northern temperate lakes in North America and Europe (Lasenby et al., 1986). M. relicta are known for their diel vertical migrations (Beeton, 1960), omnivory (Lasenby \& Langford, 1973; Grossnickle, 1979; Parker, 1980), and plasticity of life history traits (Morgan, 1980; Beeton \& Gannon, 1991). M. relicta can affect food web structure because of their mobility and omnivory. As a predator, M. relicta can alter zooplankton abundance and size structure (Almond et al., 1996). The impact M. relicta have on zooplankton populations may be why many introductions of this species have not benefited fish populations (Chess \& Stanford, 1998). In the Laurentian Great Lakes, forage fish such as rainbow smelt (Osmerus mordax Mitchell), bloater (Coregonus hoyi Gill), alewife (Alosa pseudoharengus Wilson), and deepwater sculpin (Myoxocephalus thompsoni Girard) consume M. relicta (Crowder et al., 1981; Crowder \& Crawford, 1984; Kraft \& Kitchell, 1986). M. relicta may become an even more important link in the food web as the macroinvertebrate Diporeia spp. declines throughout Lake Michigan (Nalepa et al., 2000).

Our first objective was to evaluate the large-scale spatial distribution, abundance, biomass, and pro- 
duction of $M$. relicta in southern and central Lake Michigan in the spring, summer and autumn at nearshore and offshore stations. We expected that mysids might be more abundant at the more northern stations based on data from 1985-1989 (Lehman et al., 1990). However, a study in Lake Ontario determined that lakewide differences in abundance of $M$. relicta were related to differences in bottom depth and seasonal variation, but not to geographic location (Johannsson, 1995). Previous studies have examined seasonal and annual variation in abundance and population dynamics of $M$. relicta in Lake Michigan and Ontario (Reynolds \& DeGraeve, 1972; Morgan \& Beeton, 1978; Grossnickle \& Morgan, 1979; Johannsson, 1992; Pothoven et al., 2000). However, these studies were done in only one small geographic area of each lake. We also evaluated the abundance of mysids on a smaller regional scale during late spring to help determine if abundance patterns differed at stations located in relatively close proximity to each other.

The second objective of this study was to determine if there were any large-scale spatial differences in life history traits and population structure of mysids in Lake Michigan. Reproductive traits of mysids can differ across gradients of primary productivity (Morgan, 1980; Beeton \& Gannon, 1991). However, total phosphorus, an indicator of primary productivity, does not currently differ substantially between northern and southern Lake Michigan at offshore sites (Fahnenstiel et al., 1998), so we did not believe there would be any spatial variation in life history traits.

\section{Methods}

Sampling was conducted at 16 nearshore and offshore stations along eight transects in Lake Michigan (Fig. 1). Sampling took place in the spring (March 23-April 11, 2000), summer (July 17-August 11, 2000) and autumn (September 12-October 18, 2000). The bottom depth was $45 \mathrm{~m}$ at nearshore stations and 100-110 m at offshore stations, except off St. Joseph (75 m). Sampling did not occur off Sheboygan in the spring or Grand Haven in the autumn. The sampling stations were located in the southern and central basins of Lake Michigan (Nalepa et al., 2000). The southern basin has a gentle slope and a maximum depth of $163 \mathrm{~m}$. Most major tributaries to Lake Michigan are located in the southern basin. The central basin includes a mid-lake ridge, several depositional basins, and has a maximum depth of $240 \mathrm{~m}$. Sampling was also conducted June 2-4, 2000 at 4 nearshore and 4 offshore stations along transects off Whitehall, Muskegon, Mona Lake, and Grand Haven, Michigan to evaluate smaller scale regional spatial distribution of M. relicta (Fig. 1). The distance between the most southern transect (Grand Haven) and most northern transect (Whitehall) was approximately $37 \mathrm{~km}$.

Triplicate samples of $M$. relicta were collected at each station using a $1 \mathrm{~m}$ diameter plankton net with a $3 \mathrm{~m}$ long cone (1000- $\mu \mathrm{m}$ mesh). The net was towed vertically from near bottom to the surface at speeds of $0.5 \mathrm{~m} \mathrm{~s}^{-1}$. Sampling began at least $1 \mathrm{~h}$ after sunset. Mysids were anesthetized with carbonated water and preserved in 10\% sugar-buffered formalin. Body length, sex, and eggs per female were recorded for each individual. Body length was measured from the tip of rostrum to the tip of the telson. Sex was determined by examining the structure of the fourth pleopod, which bifurcates in males (Balcer et al., 1984). Sex was only determined for individuals over $10 \mathrm{~mm}$, because the sex of most of the smaller individuals was not distinguishable. Brood size for females was calculated as the number of eggs plus embryos present.

A length-weight equation (Shea \& Makarewicz, 1989) was used to convert lengths of individual M. relicta to dry weight. Mean seasonal biomass density was calculated for the southern and central basins of Lake Michigan. Seasonal biomass was averaged to determine mean annual biomass density for each basin. Winter biomass was assumed to be the same as spring because winter growth is low (Pothoven et al., 2000). We estimated a range of production rates $(\mathrm{P})$ for each basin using our calculated biomass density (B) and the highest and lowest $\mathrm{P}: \mathrm{B}$ ratios (2.2 to 3.3 ) that were derived by Sell (1982) from four previous studies of Mysis in Lake Michigan. Standing stock (total biomass) was determined for each basin for the 50$100 \mathrm{~m}$ depth range by multiplying the biomass density estimates by the area between the two depth contours.

A Seabird CTD with an attached Sea Tech fluorometer was cast at each station after dark when $M$. relicta were collected. Discrete water samples were collected with a Niskin bottle from $5 \mathrm{~m}$ below the surface in March. Water samples were taken from the epilimnion, deep chlorophyll layer, and hypolimnion (based on real-time CTD cast data) in July and September. To determine chlorophyll levels, duplicate water samples from each depth were filtered onto Whatman $\mathrm{GF} / \mathrm{F}$ filters, extracted with N,N-dimethylformamide, and analyzed fluorometrically. The chlorophyll data from the water samples was used to calibrate the fluoro- 


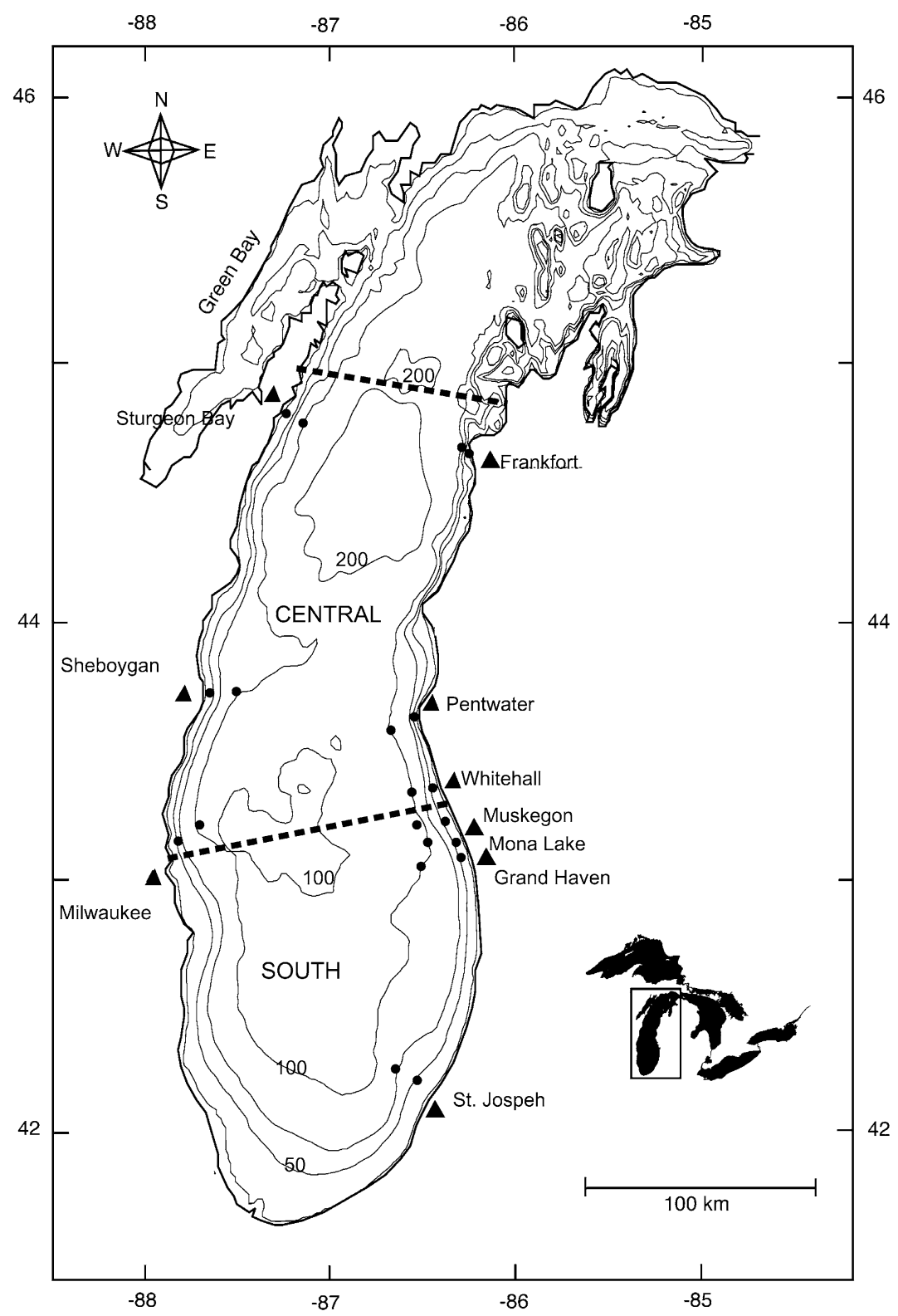

Figure 1. Map of Lake Michigan and locations of nearshore (45) and offshore (75-110 m) sampling stations. The dashed line designates the south and central basins. Bottom depth along contours given in meters.

meter cast data using linear regression $\left(r^{2}=0.95\right)$. The calibrated fluorometer data was averaged over the entire water column to calculate average chlorophyll concentration at each station.

The mean numerical density of $M$. relicta during each season was compared among seasons, transects, and nearshore and offshore with separate ANOVAs. The seasonal abundance of mysids at nearshore and offshore stations was compared separately among loc- ations using pairwise comparisons (Tukey's HSD). Pearson correlation analysis was used to examine the relationship between the mean density of $M$. relicta and station total depth, bottom water temperature, surface water temperature, and mean water column chlorophyll concentration. Probabilities for correlation coefficients were determined with Bonferroni tests. The proportion of females with broods was compared among transects using chi-square analysis. The 


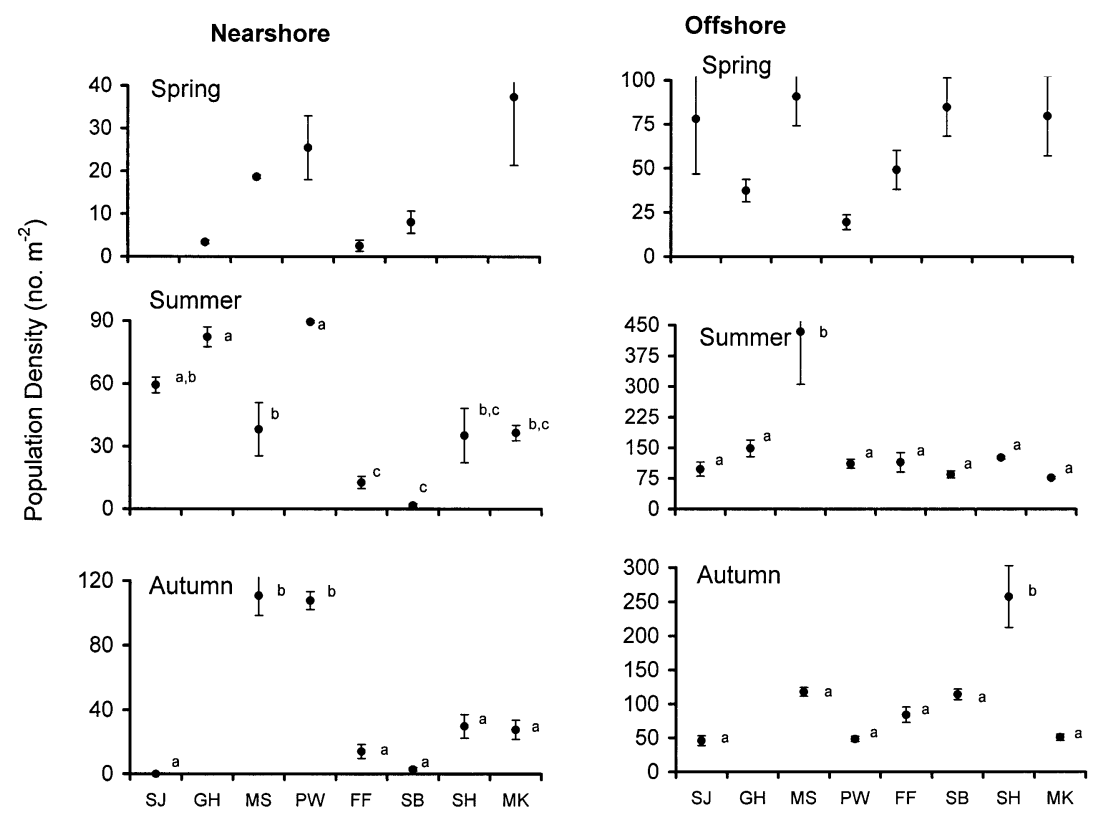

Figure 2. Mean numerical density (triplicate net tows) $\pm 1 \mathrm{SE}$ of Mysis relicta at 8 locations in Lake Michigan in spring, summer and autumn at nearshore and offshore stations. Abbreviations of locations follow: SJ = St. Joseph, MI; GH = Grand Haven, MI; MS = Muskegon, MI; $\mathrm{PW}=$ Pentwater, MI; FF = Frankfort, MI; SB = Sturgeon Bay, WI; SH = Sheboygan, WI; MW = Milwaukee, WI. Abundances at stations with common letters were not significantly different (Tukey's test).

Table 1. Bottom water temperature, surface water temperature and average water column chlorophyll concentration at eight nearshore (45 m) and offshore (75-110 m) stations in Lake Michigan in 2000.

\begin{tabular}{|c|c|c|c|c|c|c|c|c|c|}
\hline \multirow[t]{2}{*}{ Transect } & \multicolumn{3}{|l|}{ Spring } & \multicolumn{3}{|l|}{ Summer } & \multicolumn{3}{|l|}{ Fall } \\
\hline & $\begin{array}{l}\text { Bottom } \\
\text { (C) }\end{array}$ & $\begin{array}{l}\text { Surface } \\
\text { (C) }\end{array}$ & $\begin{array}{l}\mathrm{CHL}_{\mathrm{a}} \\
\left(\mu \mathrm{g}^{-1}\right)\end{array}$ & $\begin{array}{l}\text { Bottom } \\
\text { (C) }\end{array}$ & $\begin{array}{l}\text { Surface } \\
\text { (C) }\end{array}$ & $\begin{array}{l}\mathrm{CHL}_{\mathrm{a}} \\
\left(\mu \mathrm{g}^{-1}\right)\end{array}$ & $\begin{array}{l}\text { Bottom } \\
\text { (C) }\end{array}$ & $\begin{array}{l}\text { Surface } \\
\text { (C) }\end{array}$ & $\begin{array}{l}\mathrm{CHL}_{\mathrm{a}} \\
\left(\mu \mathrm{g}^{-1}\right)\end{array}$ \\
\hline \multicolumn{10}{|l|}{ Nearshore } \\
\hline St. Joseph, MI & - & - & - & 5 & 23 & 1.2 & 10 & 15 & 1.7 \\
\hline Grand Haven, MI & 3 & 3 & 2.8 & 5 & 15 & 0.9 & - & - & - \\
\hline Muskegon, MI & 3 & 3 & 3.1 & 5 & 19 & 1.0 & - & - & - \\
\hline Pentwater, MI & 4 & 4 & 1.8 & 8 & 22 & 1.3 & 12 & 13 & 2.4 \\
\hline Frankfort, MI & 4 & 4 & 1.9 & 4 & 14 & 0.9 & 9 & 19 & 1.2 \\
\hline Sturgeon Bay, WI & 3 & 3 & 2.9 & 11 & 18 & 0.9 & 5 & 18 & 0.8 \\
\hline Sheboygan, WI & - & - & - & 9 & 18 & 0.9 & 5 & 10 & 0.3 \\
\hline Milwaukee, WI & 3 & 3 & 2.9 & 9 & 18 & 1.0 & 5 & 15 & 0.7 \\
\hline \multicolumn{10}{|l|}{ Offshore } \\
\hline St. Joseph, MI & 4 & 4 & - & 4 & 22 & 1.1 & 5 & 15 & 1.5 \\
\hline Grand Haven, MI & 4 & 4 & 2.2 & 4 & 20 & 0.7 & - & - & - \\
\hline Muskegon, MI & 4 & 4 & 2.2 & 4 & 20 & 0.7 & - & - & - \\
\hline Pentwater, MI & 4 & 4 & 2.8 & 5 & 22 & 1.0 & 5 & 13 & 1.3 \\
\hline Frankfort, MI & 4 & 4 & 1.7 & 4 & 15 & 0.8 & 4 & 19 & 1.1 \\
\hline Sturgeon Bay, WI & 3 & 3 & 2.5 & 4 & 17 & 1.1 & 4 & 20 & 0.4 \\
\hline Sheboygan, WI & - & - & - & 4 & 19 & 0.8 & 4 & 16 & 0.5 \\
\hline Milwaukee, WI & 3 & 3 & 2.3 & 4 & 19 & 1.3 & 4 & 21 & 0.5 \\
\hline
\end{tabular}


mean length of females with broods was compared among transects using ANOVA. Because brood size varied with female length $(P<0.001)$, brood size was compared among transects and between nearshore and offshore stations using ANCOVA. Chi-square analysis was used to compare the proportion of juveniles $(<10 \mathrm{~mm})$ and adults $(\geq 10 \mathrm{~mm})$ among transects and seasons. Standardized residuals were examined to determine differences from expected values. All statistical analysis was done using SYSTAT 8.0 with $\mathrm{P}$-values of 0.05 considered significant.

\section{Results}

For the lake wide sampling, water temperature was generally low $\left(3\right.$ to $4{ }^{\circ} \mathrm{C}$ ) in the spring and varied little among sites (Table 1). In the summer and autumn, surface water temperatures were variable among both nearshore and offshore stations. In contrast, summer and autumn bottom water temperatures differed more among nearshore stations than among offshore stations. The average chlorophyll concentration in the spring was higher than during summer and fall, and was generally higher nearshore than offshore (Table 1). Mean chlorophyll concentration differed little among transects or between nearshore and offshore in the summer. In contrast, chlorophyll concentrations differed widely among transects and were generally higher nearshore than offshore in the autumn. During June, surface water temperatures ranged from $11^{\circ} \mathrm{C}$ (Muskegon) to $13^{\circ} \mathrm{C}$ (Grand Haven, Mona Lake) at nearshore stations and from $10^{\circ} \mathrm{C}$ (Mona Lake, Muskegon) to $13^{\circ} \mathrm{C}$ (Whitehall) at offshore stations. Bottom water temperatures were $4^{\circ} \mathrm{C}$ (nearshore) or $5^{\circ} \mathrm{C}$ (offshore) at all locations in June.

The lake-wide numerical density of mysids in Lake Michigan differed by season $(F=5.25 ; \mathrm{df}=2$, 126; $P<0.01)$, transect $(F=2.89 ; \mathrm{df}=7,121$; $P<0.01)$, and between nearshore and offshore $(F=$ $29.82 ; \mathrm{df}=1,127 ; P<0.01)$. The overall abundance of Mysis was highest in summer $\left(108 \mathrm{~m}^{-2}\right)$ and lowest in the spring $\left(41 \mathrm{~m}^{-2}\right)$, and abundance was higher offshore $\left(107 \mathrm{~m}^{-2}\right)$ than nearshore $\left(35 \mathrm{~m}^{-2}\right)$. The mean abundance of Mysis was positively correlated with bottom depth $(r=0.55, P<0.001, n=40)$, but not with bottom water temperature $(r=-0.16)$, surface water temperature $(r=0.32)$, or mean chlorophyll concentration $(r=-0.30)$.

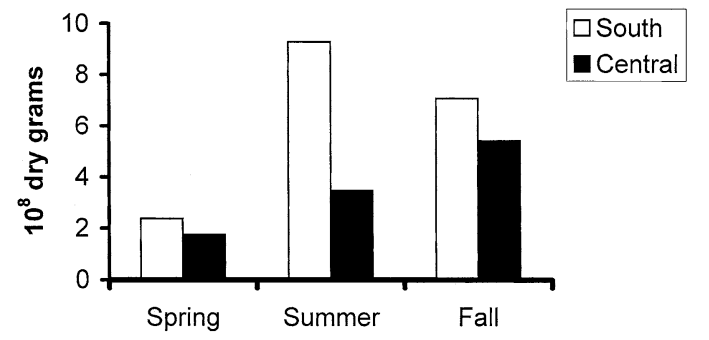

Figure 3. Mean total seasonal biomass $\left(10^{8} \mathrm{~g}\right.$ dry weight $)$ of mysids in the south and central basins of Lake Michigan in 2000.

In the spring, pairwise comparisons indicated that the numerical density of $M$. relicta did not differ significantly among nearshore or offshore stations (Fig. 2). The mean coefficient of variation among replicates was $49 \%$ at nearshore stations and $41 \%$ at offshore stations in the spring. In the summer, the numerical density of $M$. relicta differed among nearshore stations, with relatively high abundance off Pentwater and Grand Haven, and relatively low abundance off Sturgeon Bay and Frankfort (Fig. 2). The abundance of M. relicta was similar among all offshore stations in the summer, with the exception of Muskegon, where the numerical density was significantly higher than at other offshore stations (Fig. 2). In the autumn, the numerical density of $M$. relicta was similar among all nearshore stations with the exception of Muskegon and Pentwater, where abundance was relatively high (Fig. 2). The abundance of $M$. relicta was similar among all offshore stations in the autumn with the exception of Sheboygan, where numerical density was significantly higher than at other offshore stations (Fig. 2). The mean coefficient of variation was $36 \%$ and $38 \%$ at nearshore stations and $24 \%$ and $19 \%$ at offshore stations in the summer and autumn respectively. The density of mysids was higher offshore than nearshore for each transect in all instances except for in the spring and autumn off Pentwater and in the autumn off Muskegon.

Total biomass was higher in the southern basin than in the central basin for each season (Fig. 3). Biomass of mysids was lowest in the spring in each basin and highest in the summer (southern basin) or in the fall (central basin). The annual production rate was $0.23-0.34 \mathrm{~g}$ dry weight $\mathrm{m}^{-2} \mathrm{yr}^{-1}$ in the southern basin, and 0.16 to $0.23 \mathrm{~g}$ dry weight $\mathrm{m}^{-2} \mathrm{yr}^{-1}$ in the central basin. Estimates for annual areal production were $1.16-1.74 \times 10^{9} \mathrm{~g}$ dry weight in the southern basin and $0.68-1.02 \times 10^{9} \mathrm{~g}$ dry weight in the central basin. 


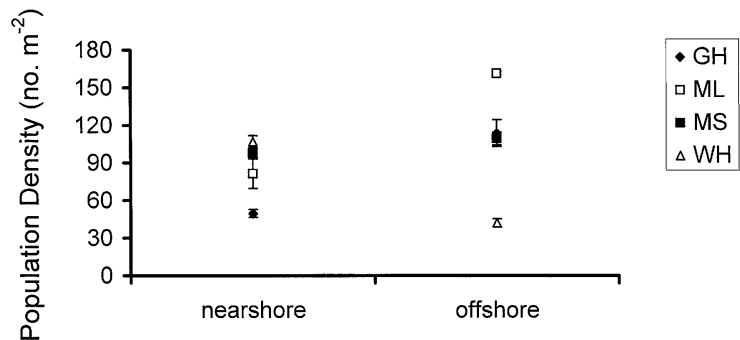

Figure 4. Mean numerical density (triplicate net tows) \pm 1 SE of Mysis relicta in June 2000 at nearshore and offshore stations along 4 transects in southeast Lake Michigan. GH = Grand Haven; $\mathrm{ML}=$ Mona Lake; MS = Muskegon; WH = Whitehall.

Within a smaller region in southeast Lake Michigan, the abundance of $M$. relicta differed among transects at both nearshore $(F=14.2 ; \mathrm{df}=3,8$; $P<0.01)$ and offshore $(F=62.2 ; \mathrm{df}=3,8$; $P<0.01$ ) stations (Fig. 4). Pairwise comparisons indicated that the abundance of Mysis was lower off Grand Haven than at three other nearshore stations in the area. For offshore stations, the abundance of M. relicta was lowest off Whitehall and relatively high off Mona Lake. The average coefficient of variation among replicates was $12 \%$ at nearshore stations and $10 \%$ at offshore stations.

The proportion of females with broods was $28 \%$ in the spring, but only $3 \%$ in the summer and $2 \%$ in the fall. At Muskegon, at least $5 \%$ of the females had broods each season. In contrast, reproductive females were only found in the summer off Frankfort and in the autumn off Sheboygan. The proportion of females with broods differed among locations $\left(\chi^{2}=32\right.$, df $=$ $7, P<0.001, n=1,171)$, ranging from $1 \%$ off Sheboygan to $14 \%$ off Sturgeon Bay (Table 2). The mean adjusted brood size $(F=0.55$; df $=5,54$; $P=0.74)$ and the mean length of reproductive females $(F=1.4$; df $=5,55 ; P=0.22)$ did not differ among transects (Table 2). Most reproductive females were from offshore. Reproductive females were only found nearshore in the spring off Pentwater and Muskegon, in the summer off Frankfort, and in the fall off Sheboygan.

Juveniles comprised $69 \%$ of all $M$. relicta. The size distribution of mysids differed among seasons $\left(\chi^{2}=418\right.$, df $\left.=2, P<0.001, n=7,294\right)$, transects $\left(\chi^{2}=172\right.$, df $\left.=7, P<0.001, n=7,294\right)$, and between nearshore and offshore $\left(\chi^{2}=24\right.$, df $=$ $1, P<0.001, n=7,294)$. Seasonally, there was a higher proportion of mysids that were juveniles in the spring $(79 \%)$ and summer $(76 \%)$ than in the autumn $(54 \%)$. The percentage of mysids that were juveniles was higher offshore $(71 \%)$ than nearshore $(64 \%)$. Overall, there was a relatively high percentage of juveniles collected off Grand Haven (80\%) and a relatively low percentage of juveniles off Sheboygan (64\%), Pentwater (60\%), and St. Joseph (56\%).

\section{Discussion}

The abundance of mysids differed among sites throughout central and southern Lake Michigan. At nearshore stations, the abundance of mysids was lower and more variable than offshore and was generally highest off Pentwater. The abundance of mysids was somewhat more uniform among offshore stations and differences among sites were due mainly to high densities at one station. The abundance of mysids was not consistently high for central or southern basin sites, although overall biomass was higher in the southern basin each season. In the 1980s, a study suggested that the abundance of mysids in the summer was higher in the central and northern basins of Lake Michigan than in the southern basin (Lehman et al., 1990). The difference was probably due to deeper sampling stations further north in the 1990's study because for stations at the same bottom depth as in our study, the numbers of $M$. relicta were not consistently higher in the north (Lehman et al., 1990). In Lake Ontario, geographic location did not account for variability in the abundance of mysids, although distance from the north-south and east-west axes of the lake were used to determine location (Johannsson, 1995). In Emerald Bay in Lake Tahoe, California-Nevada, the abundance of $M$. relicta differed four to eleven-fold at two nearshore stations on opposite ends of the lake during May-September (Morgan \& Threlkeld, 1982).

In addition to lake wide variation, the abundance of $M$. relicta also differed among stations that were located in a relatively small regional area. This suggests that patchy spatial distribution may be a defining characteristic of mysids regardless of the scale of the observation area. A number of factors could influence the distribution of mysids at a regional or lake wide level. For example, the spatial distribution of zooplankton prey could influence the spatial distribution of $M$. relicta (Morgan \& Threlkeld, 1982). Zooplankton are spatially diverse on a regional and local level in the Great Lakes (Stockwell \& Sprules, 1995) and could indirectly affect the distribution of their predators such as M. relicta (Rose \& Leggett, 1990; Johannsson et al., 2001). Fish abundance also varies throughout Lake 
Table 2. Reproductive characteristics of Mysis relicta in Lake Michigan in 2000. Female lengths with common letters were not significantly different (Tukey's test). Brood size is reported as the adjusted mean (ANCOVA). Significant differences in brood size (ANCOVA) and percent females with broods $\left(\chi^{2}\right)$ among transects are noted with an asterisk. Sheboygan and Frankfort were excluded from brood size and female size analyses. $N=$ number of reproductive females. A significance level of 0.05 was used for all tests.

\begin{tabular}{lllllr}
\hline & & $\begin{array}{l}\text { Female length } \\
(\mathrm{mm}) \\
(\mathrm{mean} \pm 1 \mathrm{SE})\end{array}$ & $\begin{array}{l}\text { Brood size } \\
(\text { mean } \pm 1 \mathrm{SE})\end{array}$ & $\begin{array}{l}\text { Females with } \\
\text { broods (\%) }\end{array}$ & $N$ \\
\hline \multirow{2}{*}{ Transect } & St. Joseph, MI & $16 \pm 1.0^{\mathrm{Z}}$ & $21 \pm 1.8$ & $3^{*}$ & 4 \\
& Grand Haven, MI & $16 \pm 0.8^{\mathrm{Z}}$ & $19 \pm 1.5$ & 8 & 6 \\
& Muskegon, MI & $16 \pm 0.4^{\mathrm{Z}}$ & $18 \pm 2.1$ & 7 & 17 \\
& Pentwater, MI & $15 \pm 0.5^{\mathrm{Z}}$ & $17 \pm 2.1$ & 6 & 12 \\
& Sturgeon Bay, WI & $16 \pm 0.3^{\mathrm{Z}}$ & $20 \pm 1.4$ & 14 & 8 \\
& Milwaukee, WI & $15 \pm 0.3^{\mathrm{Z}}$ & $21 \pm 2.4$ & 9 & 1 \\
& Sheboygan, WI & 18 & 27 & 1 & 2 \\
\hline
\end{tabular}

Michigan (Fabrizio et al., 2000), so variation in predation pressure could result in spatial differences in the abundance of mysids (Lehman et al., 1990). Little work has been done relating the abundance of fish to $M$. relicta distribution and offshore predators such as deepwater sculpins are ignored in most food web analyses (Brandt et al., 1991; Rand et al., 1995).

The physical environment can also affect the lakewide distribution of mysids. $M$. relicta were often most abundant in mid-lake areas where strong currents from the northern and southern basins converge (Beletsky et al., 1999). M. relicta may be passively transported into areas where currents converge (Johannsson, 1995) or these areas might also have higher primary productivity and therefore support more $M$. relicta (Rand et al., 1995), but we did not find evidence that chlorophyll concentration was related to the abundance of mysids. Upwelling can also produce spatial variability of mysids at nearshore stations. The abundance of $M$. relicta increased in nearshore areas of Lakes Michigan and Ontario after upwelling events (Reynolds \& DeGraeve, 1972; Shea \& Makarewicz, 1989; Johannsson, 1992). However, upwelling did not result in unusually high numbers of $M$. relicta at nearshore stations off Grand Haven in the summer or Sturgeon Bay, Sheboygan, and Milwaukee in the fall of this study. Moreover, the most consistently high densities of $M$. relicta at a nearshore station off Pentwater were not associated with upwelling. Pentwater is also a convergence area for bottom and wind driven circulation currents that could passively transport mysids into the nearshore region. Finally, storms, advection, and internal thermal oscillations also are known to redistribute zooplankton in Lake Michigan (Miller, 2003).

The lake wide and regional patchy distribution of mysids can pose problems when estimating production and consumption by mysids (Gal et al., 1999). For example, in the southern basin, where most monitoring of mysids has taken place (Lehman et al., 1990; Pothoven et al., 2000), the production estimates from any one location relative to the overall average production for the basin could be $30 \%$ higher or $20 \%$ lower depending on which location was chosen to represent the basin. Depending on the goals of modeling or food web exercises, the lake wide and regional spatial variation may or may not be an important factor to consider because of annual variation in abundance (Pothoven et al., 2000) and the occasional relatively high CV.

Because few studies have sampled mysids throughout Lake Michigan, there is little data on the lakewide biomass or production of this species. The production rates in our study $\left(0.16-0.34 \mathrm{~g}\right.$ dry weight $\left.\mathrm{m}^{-2} \mathrm{yr}^{-1}\right)$ were generally lower than for previous studies in Lake Michigan during 1954-1976 (0.25-3.2 g dry weight $\mathrm{m}^{-2} \mathrm{yr}^{-1}$ ) (Sell, 1982). The differences could reflect differences in sample depths (Sell, 1982), station location, or changes in mysid populations over the past 50 years. The production rates for this study in Lake Michigan were also lower than the produc- 
tion rates $\left(0.91 \mathrm{~g}\right.$ dry weight $\left.\mathrm{m}^{-2} \mathrm{yr}^{-1}\right)$ for $50-100 \mathrm{~m}$ depths in Lake Ontario (Johannsson, 1995).

As expected, brood size and size of reproductive females did not differ among lake wide sampling locations. Both brood size and size of reproductive females have been correlated with primary productivity (Morgan, 1980; Beeton \& Gannon, 1991). Presently, chlorophyll concentration (this study) and total phosphorus (Fahnenstiel et al., 1998) do not differ substantially between northern and southern Lake Michigan at offshore sites, so the similarity in brood and female lengths throughout the lake is not surprising. In contrast, the differences in brood size and age at reproduction in Lake Tahoe, California-Nevada and Emerald Bay were associated with a threefold difference in productivity (Morgan, 1980; Beeton \& Gannon, 1991). The proportion of females with broods did differ among transects and the timing and duration of reproduction also differed somewhat among transects, e.g., reproduction appeared to occur throughout the year off Muskegon, but only during one season at several other locations. These differences may reflect differences in prey availability (Beeton \& Gannon, 1991), phenotypic plasticity (Morgan, 1980; Beeton \& Gannon, 1991), or patchy distribution or poor sampling efficiency of larger, reproductive $M$. relicta (Grossnickle \& Morgan, 1979).

The size distribution of $M$. relicta differed throughout Lake Michigan. Variability in the size structure of mysids could be related to a number of factors, including patchy distribution of mysids, sampling efficiency (Grossnickle \& Morgan, 1979), patchy distribution of fish predation (Brandt et al., 1991), and timing and duration of reproduction (Johannsson, 1992). Differences in size distribution affect estimates of biomass and production.

Most studies of $M$. relicta account for spatial variability along depth gradients. However, few studies sample multiple stations of the same bottom depth. Our results indicate that abundance and some life history traits of $M$. relicta are variable on a small and large scale within Lake Michigan at nearshore and offshore sites. Sampling methodologies such as acoustics and Acoustic Doppler Current Profilers that could effectively evaluate patchiness of $M$. relicta need to be developed as a compliment to traditional net sampling to better evaluate mysid abundance and biomass (Gal et al., 1999; Miller, 2003). Future sampling of $M$. relicta should be done in conjunction with studies of zooplankton and fish abundance, fish diet, and the physical environment in order to provide a better understanding of the factors that influence the distribution, abundance, and life history this species that is a key link in the Great Lakes food web.

\section{Acknowledgements}

A. Hauxwell provided assistance in the laboratory. The crew of the R/V Shenehon and R/V Laurentian, D. Hondorp, J. Selbig, S. Rypma, and L. Florence provided assistance in the field. GLERL contribution 1301.

\section{References}

Almond, M. J. R., E. Bentzen \& W. D. Taylor, 1996. Size structure and species composition of plankton communities in deep Ontario lakes with and without Mysis relicta and planktivorous fish. Canadian Journal of Fisheries and Aquatic Sciences 53: 315-325.

Balcer, M. D., N. L. Korda \& S. I. Dodson, 1984. Zooplankton of the Great Lakes. A Guide to the Identification and Ecology of the Common Crustacean Species. The University of Wisconsin Press, Wisconsin, 175 pp.

Beeton, A. M., 1960. The vertical migration of Mysis relicta in Lakes Huron and Michigan. Journal of the Fisheries Research Board of Canada 17: 517-539.

Beeton, A. M. \& J. E. Gannon, 1991. Effect of environment on reproduction and growth of Mysis relicta. American Fisheries Society Symposium 9: 144-148.

Beletsky, D., S. H. Saylor \& D. J. Schwab, 1999. Mean circulation in the Great Lakes. Journal of Great Lakes Research 25: 78-93.

Brandt, S. B, D. M. Mason, E. V. Patrick, R. L. Argyle, L. Wells \& D. J. Stewart, 1991. Acoustic measures of the abundance and size of pelagic planktivores in Lake Michigan. Canadian Journal of Fisheries and Aquatic Sciences 48: 894-908.

Chess, D. W. \& J. A. Stanford, 1998. Comparative energetics and life cycle of the opossum shrimp (Mysis relicta) in native and non-native environments. Freshwater Biology 40: 783-794.

Crowder, L. B., J. J. Magnuson \& S. B. Brandt, 1981. Complementarity in the use of food and thermal habitat by Lake Michigan fishes. Canadian Journal of Fisheries and Aquatic Sciences 38: 662-668.

Crowder, L. B. \& H. L. Crawford, 1984. Ecological shifts in resource use by bloaters in Lake Michigan. Transactions of the American Fisheries Society 113: 694-700.

Fabrizio, M. C., J. Raz \& R. R. Bandekar. 2000. Using linear models with correlated errors to analyze changes in abundance of Lake Michigan fishes: 1973-1992. Canadian Journal of Fisheries and Aquatic Sciences 57: 775-788.

Fahnenstiel, G. F., A. E. Krause, M. M. McCormick, H. J. Carrick \& C. L. Schelske, 1998. The structure of the planktonic food-web in the St. Lawrence Great Lakes. Journal of Great Lakes Research 24: 531-554.

Gal, G., L. G. Rudstam \& C. H. Greene, 1999. Acoustic characterization of Mysis relicta. Limnology and Oceanography 44: 371-381.

Grossnickle, N. E., 1979. Nocturnal feeding patterns of Mysis relicta in Lake Michigan based on gut content fluorescence. Limnology and Oceanography 24: 777-780. 
Grossnickle, N. E. \& M. D. Morgan, 1979. Density estimates of Mysis relicta in Lake Michigan. Journal of the Fisheries Research Board of Canada 36: 694-698.

Johannsson, O. E., 1992. Life history and productivity of Mysis relicta in Lake Ontario. Journal of Great Lakes Research 18: 154-168.

Johannsson, O. E., 1995. Responses of Mysis relicta population dynamics and productivity to spatial and seasonal gradients in Lake Ontario. Canadian Journal of Fisheries and Aquatic Sciences 52: 1509-1522.

Johannsson, O. E., M. F. Leggett, L. G. Rudstam, M. R. Servos, M. A. Mohammadian, G. Gal, R. M. Dermott \& R. H. Hesslein, 2001. Diet of Mysis relicta in Lake Ontario as revealed by stable isotope and gut content analysis. Canadian Journal of Fisheries and Aquatic Sciences 58: 1975-1986.

Kraft, C. E. \& J. F. Kitchell, 1986. Partitioning of food resources by sculpins in Lake Michigan. Environmental Biology of Fishes 16: 309-316.

Lasenby, D. C. \& R. R. Langford, 1973. Feeding assimilation of Mysis relicta. Limnology and Oceanography 18: 280-285.

Lasenby, D. C., T. G. Northcote \& M. Furst, 1986. Theory, practice, and effects of Mysis relicta introductions to North American and Scandinavian lakes. Canadian Journal of Fisheries and Aquatic Sciences 43: 1227-1284.

Lehman, J. T., J. A. Bowers, R. W. Gensemer, G. J. Warren \& D. K. Branstrator, 1990. Mysis relicta in Lake Michigan: Abundances and relationships with their potential prey, Daphnia. Canadian Journal of Fisheries and Aquatic Sciences 47: 977-983.

Miller, G. S. 2003. Mysis vertical migration in Grand Traverse Bay, Lake Michigan, observed by an acoustic Doppler current profiler. Journal of Great Lakes Research 29: 427-435.

Morgan, M. D, 1980. Life history characteristics of two introduced populations of Mysis relicta. Ecology 61: 551-561.

Morgan, M. D. \& A. M. Beeton, 1978. Life history and abundance of Mysis relicta in Lake Michigan. Journal of the Fisheries Research Board of Canada 35: 1165-1170.
Morgan, M. D. \& S. T. Threlkeld, 1982. Size dependent horizontal migration of Mysis relicta. Hydrobiologia 93: 63-68.

Nalepa, T. F., D. J. Hartson, J. Buchanan, J. F. Cavaletto, G. A. Lang \& S. J. Lozano, 2000. Spatial variation in density, mean size and physiological condition of the holarctic amphipod Diporeia spp. in Lake Michigan. Freshwater Biology 43: 107-119.

Parker, J. I, 1980. Predation by Mysis relicta on Pontoporeia hoyi: A food link of potential importance in the Great Lakes. Journal of Great Lakes Research 6: 164-166.

Pothoven, S.A., G. L. Fahnenstiel, H. A. Vanderploeg \& M. Luttenton, 2000. Population Dynamics of Mysis relicta in southeastern Lake Michigan, 1995-1998. Journal of Great Lakes Research 26: 357-365.

Rand, P. S., D. J. Stewart, B. F. Lantry, L. G. Rudstam, O. E. Johannsson, A. P. Goyke, S. B. Brandt, R. O'Gorman \& G. W. Eck, 1995. Effect of lake-wide planktivory by the pelagic prey fish community in Lakes Michigan and Ontario. Canadian Journal of Fisheries and Aquatic Sciences 52: 1546-1563.

Reynolds, J. B. \& G. M DeGraeve, 1972. Seasonal population characteristics of the opossum shrimp, Mysis relicta, in southeastern Lake Michigan, 1970-71. Proceedings of the 15th Conference of Great Lakes Research, International Association of Great Lakes Research, pp. 117-131.

Rose, G. A. \& W. C. Leggett, 1990. The importance of scale to predator-prey spatial correlations: an example of Atlantic fishes. Ecology 71: 33-43.

Sell, D. W., 1982. Size-frequency estimates of secondary production by Mysis relicta in Lakes Michigan and Huron. Hydrobiologia 93: 69-78.

Shea, M. A. \& J. C. Makarewicz, 1989. Production, biomass and trophic interactions of Mysis relicta in Lake Ontario. Journal of Great Lakes Research 15: 223-232.

Stockwell, J. D. \& W. G. Sprules, 1995. Spatial and temporal patterns of zooplankton biomass in Lake Erie. ICES Journal of Marine Sciences 52: 557-564. 